\title{
Keruangan Perkotaan Medan dalam Tinjauan Transportasi Perkotaan Masa Kolonial
}

\author{
Syaiful Anwar \\ Dosen Pendidikan Sejarah, FKIP Universitas Islam Sumatera Utara \\ ikpoel@gmail.com
}

\begin{abstract}
This research discusses the development of urban transport in Medan during the first half of $20^{\text {th }}$ century. In this period, Medan was the city at outside Java that had the most good strides in social and economic life. Although the urban situation had a remarkable development, but the transport system was not complicated as well as Batavia or Surabaya. Therefore, the problem of this thesis emphasize the urban transportation development in the midst of Medan urban's development. The urban spaces, the dynamics of employing transportation, and regulation are some important factors which discuss in this thesis. This research analyzing primary and secondary sources which include archives, newspapers, magazines, photographs, and other references. There are several findings in this thesis. First, most of the urban streets in Medan were built originally for the plantation needs, before then became the public road and the urban main street. Second, although the mechanic vehicle had existed, but generally, the urban center was filled by the smaller number of upper middle class rather than lower middle class groups which generally live at suburbs. Third, the policy on the Medan urban transport system was not fully held by the city government, because the other parties of nongovernment also intervenes to adjust their personal or group interests. Fourth, public transport which could carry mass passenger tends to be marginalized by economic reasons, i.e. the economic opportunity where people engaged in transportation was lost and effect on peoples income. Fifth, the sorts of urban transport in Medan are connoting also to social symbol.
\end{abstract}

Keywords: Development, transportation, city, spatial.

\section{PENDAHULUAN}

Di paruh pertama abad ke-20, Medan adalah kota yang dianggap paling modern di luar Pulau Jawa. Perkembangan industri perkebunan meningkat secara mengagumkan dan membentuk Medan sebagai pusat segala aktivitas di Sumatera Timur. Posisinya yang dekat di jalur perdagangan Selat Malaka mendukung semuanya. Maka salah satu dampaknya adalah pertumbuhan penduduk yang mempengaruhi perkembangan infrastruktur perkotaan, terutama yang berkaitan dengan mobilitas masyarakat.

Sejak permulaan abad pembangunan infrastruktur jalan-termasuk infrastruktur lainnya, sebagian besar dibuat oleh pengusaha atau perusahaan perkebunan (Breman, 1997: 198). Perkembangan pusat kota meningkat secara signifikan dan mewujud seolah demi kepentingan perusahaan. Namun, di saat 
yang sama Medan adalah kota administrasi pemerintah kolonial di Sumatera Timur dengan segala bentuk kegiatan yang semua berpusat di sana. Termasuk kaum pendatang yang mencoba peruntungannya di kota itu.

Medan menjadi pusat berbagai kegiatan dan kepentingan. Semuanya mewarnai mobilitas perkotaan. Pemukiman mengelompok ke dalam bagianbagian suku hingga sub-suku; juga pemukiman yang didasarkan ekonomi. Medan memiliki keterhubungan yang dibentuk oleh jaringan transportasi perkotaan. Namun, mobilitas itu tetap belum didukung oleh salah transportasi yang kompleks seperti penggunaan trem untuk perkotaan seperti Batavia atau Surabaya yang cukup menjawab persoalan atas kepadatan penduduk yang terjadi.

Pada umumnya transportasi perkotaan di Medan bukanlah jenis angkutan masal. Kendaraan sewa yang hadir di perkotaan adalah jenis transportasi yang berkapasitas tak lebih dari dua orang atau dua penumpang. Sado, hongkong (angkong) hingga ke kendaraan mekanis seperti mobil dan sepeda motor adalah kendaraan minim penumpang. Bahkan terkadang lebih kelihatan sebagai angkutan pribadi. Karenanya transportasi perkotaan di Medan terkesan aneh; di saat penduduk beserta mobilitasnya terus meningkat, transportasi masal kurang mendapat perhatian dalam mendukung mobilitas tersebut.

Medan adalah kota yang pada paruh pertama abad ke-20 memiliki tingkat kepadatan yang cukup tinggi (Perret, 2010: 282). Menurut Catherine L. Ross (1996) pola pemukiman, kegiatan sehari-hari, pengaruh sosial, keadaan geografi, ekonomi, dan konsumsi dalam perkembangan kota dibentuk oleh transportasi. Bila kedua anggapan tersebut digabungkan, maka pertumbuhan penduduk serta perkembangan masyarakat Medan tak bisa dipisahkan dari transportasinya. Melihat pentingnya transportasi dalam mobilitas masyarakat, kajian transportasi perkotaan di Medan perlu dikemukakan untuk melihat seberapa jauh transportasi membentuk dinamika perkotaannya. Terutama melihat perkembangan kota berdasarkan sudut pandang transportasinya.

Periode paruh pertama abad ke-20 memiliki pesona teknologi transportasi mekanis yang tumbuh menakjubkan dan menjadi tolak ukur revolusi transportasi dunia. Pengaruhnya sampai ke kota-kota besar, termasuk Medan. Lantas, seperti apa dinamika perkembangan transportasi perkotaan di Medan? Sejauh mana keterlibatan pemerintah dalam menentukan kebijakan transportasi kota? Apa dampaknya ke masyarakat dan ruang perkotaan?

\section{PEMBAHASAN}

Tepat pada permulaan abad ke-20, mobil telah hadir di Medan. Menurut Dirk Buiskool (2005) mobil tersebut dimiliki oleh Tengkoe Besar dari Deli pada 1900. Namun, beberapa sumber menyatakan bahwa mobil atau auto pertama datang ke Medan pada 1902 dimiliki oleh seorang Eropa, bukan pribumi atau yang 
lainnya. Pemiliknya adalah Prof. Dr. W. Schüffner (seorang dokter perkebunan dan ketua Deli Automobiel Club). Dia membeli mobil bermerk Spyker dengan mesin 2 silinder, berpendingin air, bertenaga $5 \mathrm{hp}$ serta lampu depannya menggunakan sepasang lentera (Luhulima, 2012: 64-65). Pada 1910, ketika bisnis penjualan mobil mulai menggeliat di Hindia-Belanda, Prof. Dr. W. Schüffner membeli mobil keduanya yakni Benz Persival. Di tahun yang sama pengusaha terkenal Tjong A Fie juga memiliki mobil pertamanya.

Mobil pada awal abad ke-20 dianggap "mainan" mahal yang hampirhampir tak terjangkau oleh banyak kalangan. Selain faktor harga, teknologi mobil relatif baru oleh masyarakat. Onderdil yang sulit disertai bahan bakar yang relatif langka pada dekade pertama dan kedua awal abad ke-20 membuat masyarakat lebih beralih ke transportasi lain yang lebih bisa dijangkau.

Sepeda adalah salah satu kendaraan pribadi yang lebih terjangkau. Kendaraan yang muncul sejak abad ke-19 ini lebih efisien dalam hal harga maupun perawatan. Meskipun bagi masyarakat kebanyakan Kota Medan saat itu sepeda masih tergolong mahal, namun harga sepeda tidak segila harga kendaraan mekanisnya. Dalam beberapa sumber iklan di surat kabar yang terbit pada dekade kedua dan dekade ketiga awal abad ke-20, harga satu sepeda merk Megneet, Royal England dan Raleigh bernilai f 100 - f 300 . Sementara kendaraan mekanis seperti sepeda motor berharga f 3000 - 4000 dan mobil atau auto lebih $\mathrm{f} 6000$.
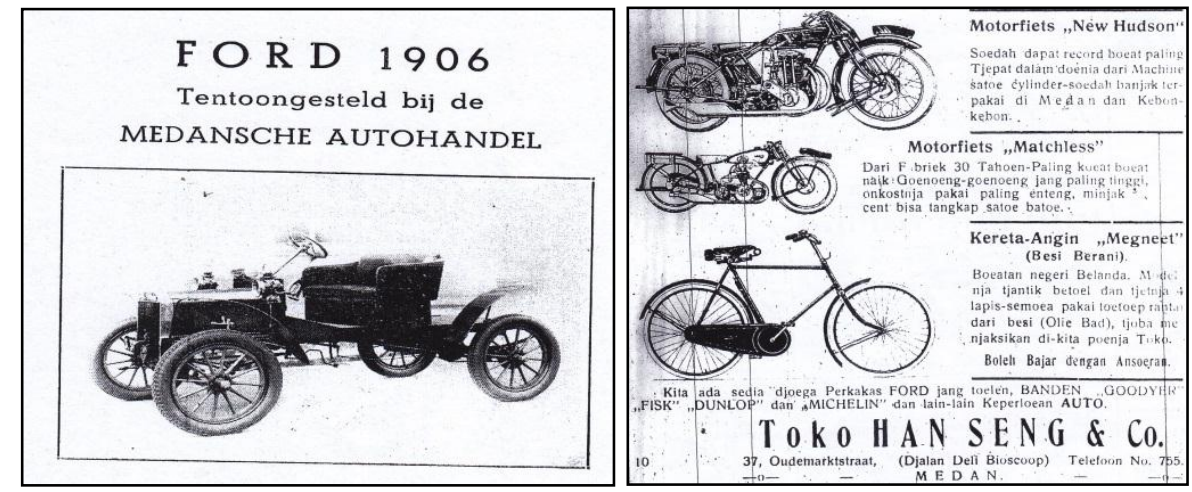

Sebelah kiri, iklan penjualan automobiel di sebuah majalah (Mededeelingen D.A.C, 1938, No. 18, hlm. 608). Sebelah kanan, iklan penjualan kendaraan roda dua (Pewarta Deli, September 1920).

Perbandingan harga yang mencolok tersebut membuat sepeda adalah kendaraan yang paling umum digunakan masyarakat perkotaan Medan. Sepanjang tahun jumlah kendaraan selalu mencolok. Pada 1918 sepeda yang terdaftar di Medan berjumlah 706 buah. Jumlah ini hampir sama dengan transportasi publik lainnya. Tetapi pada 1920, jumlah sepeda meningkat dua kali lipat sebesar 1483 buah. Peningkatan ini bersamaan dengan booming karet 
di tahun tersebut dan jumlah penduduk di perkotaan. Pada saat yang sama pula ekonomi perkotaan juga mengalami peningkatan, karena sejak walikota pertama terpilih, pembenahan infrastruktur dilakukan secara menyeluruh. Jalan-jalan diperbaiki atau ditambah untuk menghubungkan pusat-pusat aktivitas. Dua tahun kemudian, pada 1922, jumlah sepeda telah berjumlah 7649 buah (Verslag betreffende de gemeente Medanover het jaar 1928, Bijl: IX). Untuk tahun sesudahnya, laporan pemerintah tak mencatat lagi jumlah sepeda yang ada di Medan. Hal ini kemungkinan besar adalah jumlahnya yang selalu meningkat hingga sulit mencatat jumlah pastinya.

\section{Dari Pribadi Ke Publik}

Sampai akhir abad ke-19 kendaraan mekanis di negara-negara Eropa masih dianggap kurang efisien. Sewaktu Nikolaus Otto membuat mesin gas pertamanya, pada 1866, kuda telah memenuhi transportasi manusia selama nyaris 6000 tahun, dan telah beberapa dasawarsa hadir pula pelengkap transportasi berupa kereta-kereta bertenaga uap yang perannya semakin meningkat (Diamond, 2013: 301). Masyarakat masih puas dengan kereta api dan tak ada krisis ketersediaan kuda atau hewan pengangkut lainnya pada masa itu. Kendaraan mekanis lebih banyak masalahnya ketimbang manfaatnya sampai Duryea Brothers membangun mobil bermesin bensin pertama pada 1893 (Khisty dan Lall, 2005: 98). Sejak itu transportasi perkotaan mengalami perubahan besar. Mobil secara cepat menjadi alat yang serbaguna karena dapat memenuhi hasrat alami manusia untuk memperoleh mobilitas.

Di Medan, pada dekade pertama mobil telah menjadi alat transportasi. Namun, pemakaian kendaraan ini digunakan secara terbatas. Harga selalu menjadi alasan utama dalam memilikinya. Meskipun begitu, hasrat untuk menaikinya juga tinggi. Akhirnya pada 1908 perusahan taksi pertama "Verwey en Lugard" sudah hadir di Gemeente Medan (Sinar, 2011: 62) untuk memenuhi hasrat tersebut. Pada dekade kedua, iklan-iklan penyewaan mobil (auto sewa) telah banyak menghiasi koran-koran lokal.

Meskipun penyewaan mobil hadir dalam rangka memenuhi hasrat mereka akan "mainan" mahal tersebut, harga yang dipatok sebenarnya masih tergolong mahal. Terutama bagi kalangan menengah ke bawah. Tak semua kalangan bisa menikmati taksi pada awal kemunculannya. Sekali penyewaan bisa mencapai f 50 - f 100. Jumlah tersebut setara dengan sebulan pendapatan seseorang yang berasal dari kalangan menengah. Atau sekali penyewaan sama dengan harga satu sepeda baru. Sangat mahal.

Angkutan publik yang banyak digunakan pada dekade pertama dan kedua adalah kendaraan non-mekanis. Jenis pengangkutan yang diidentifikasi dalam transportasi perkotaan ada tiga jenis, yakni: sado, gerobak sapi, dan hongkong. Ketiga jenis ini paling banyak memenuhi jalanan perkotaan di Gemeente Medan pada dekade pertama dan kedua. Salah satu yang paling 
dikenal adalah kereta hongkong (angkong). Kendaraan yang ditarik manusia ini hadir semenjak pihak perkebunan menggunakan kuli-kuli Tionghoa bekerja di perkebunan, dan kalangan Tionghoa-lah yang kebanyakan jadi pengemudi kereta hongkong (Pewarta Deli, 23 Januari 1933).

Kereta hongkong pada saat pembentukan Medan menjadi gemeente, telah memenuhi sebagian besar perkotaan. Kendaraan ini digunakan sebagai alat transportasi masyarakat kota karena murah. Saat itu ongkos yang ditetapkan pemerintah berkisar antara 15 - 45 sen, tergantung jarak tempuh kendaraan. Waktu operasi hongkong ditetapkan dari pukul 06.00 pagi sampai pukul 01.00 malam. Pemberlakuan ini dikeluarkan gemeenteraad berdasarkan pemberlakuan tarif pada 1920. Lewat dari jam yang berlaku, ongkos yang harus dibayarkan penumpang harus ditambah setengah dari tarif normal.

Kereta hongkong adalah transportasi alternatif yang disukai setelah sado. Bentuknya yang ramping dapat melalui gang-gang sempit. Selain itu, kendaraan ini beroperasi lebih lama dari pada sado yang hanya sampai pukul 08.00 malam. Namun, jarak tempuhnya terbatas karena tenaga penariknya adalah manusia. Hal ini pula yang membuat orang-orang Tionghoa menjadikan hongkong sebagai mata pencaharian. Modal yang dikeluarkan tidak sebesar sado yang perlu kuda dan pakannya. Cukup dengan kotak penumpang, roda dan dua penarik di kanan dan kiri untuk ditarik oleh manusia.

Namun, pekerjaan menarik hongkong adalah pekerjaan yang sangat menghinakan bangsa sendiri karena pekerjaan demikian biasanya hanya dilakukan oleh binatang seperti kuda, lembu atau kerbau. Wacana yang dikeluarkan dalam melarang kendaraan tersebut baru terealisasi tujuh tahun kemudian, ketika pada 1925 pemerintah memutuskan tidak memberikan surat izin (vergunning) baru kepada para penarik hongkong. Namun, ketetapan ini baru berlaku pada 5 Oktober 1927 (Pewarta Deli, 5 Oktober 1927).

Pada 1927 dikabarkan bahwa para penumpang kesulitan mendapat kendaraan setelah pukul 08.00 malam. Sudah sejak lama kereta hongkong digunakan sebagai kendaraan malam. Namun sejak kereta hongkong mulai berkurang, hal tersebut berdampak juga dengan pengguna transportasi di waktu malam, terutama tengah malam. Situasi ini membuat kereta sado menambahkan jumlahnya agar bisa dioperasikan hingga malam tiba. Antara 1925 sampai 1928, jumlah kereta sado meningkat dari 600 buah menjadi 885 buah (Pewarta Deli, 15 Februari 1929).

Kereta sado sejak lama menjadi alat transportasi publik sejak Medan menjadi gemeente. Pada dekade kedua kendaraan ini pilihan utama dalam mengangkut penumpang. Selain karena bisa mengangkut lebih dari satu orang, kendaraan ini masih dipandang memiliki nilai sosial yang tinggi. Sementara itu ongkos untuk bisa menaiki kendaraan tersebut hampir sama dengan kereta hongkong. Tidak ada masalah dengan kendaraan satu ini kecuali mungkin adalah kotoran dari kuda helaan. Meskipun begitu peraturan sudah 
menjelaskan bagi pada sais sado yang harus memperhatikan kotoran kuda helaan tersebut. Hal ini juga berlaku pada gerobak sapi (ossenkarren).

Setelah Perang Dunia I, teknologi mobil mengalami perubahan besar dengan penyediaan suku cadang besar-besaran dari pabrik-pabrik yang memproduksi mobil di Eropa maupun di Batavia. Harga mobil mungkin masih terlalu tinggi untuk dimiliki secara pribadi, tetapi penyewaan kendaraan mekanis menjadi kendaraan umum semakin murah.

Sebelum kereta hongkong dilarang, kereta sado sebenarnya agak berkurang di awal dekade ketiga. Hal ini disebabkan dengan kemunculan vrach'auto dan mobil yang telah mengalami perubahan teknologi. Para sais mengeluhkannya di sebuah surat kabar lokal pada waktu, seperti yang bisa kita lihat:

"Masa ini soesah benar sado-sado dan pedati karena saingan dengan auto. Dimana ada auto sewa, sado-sado dan pedati kalah, sehingga boleh dipastikan bilangan mereka tiada akan bertambah hanja berkoerang (Pewarta Deli, 5 Juni 1922)."

“Autobus sekarang sampai tjoekoep banjaknja oentoek mengangkoet pendoedoek.... Sais sado mengeloeh - kalau doeloe pentjaharian mereka sampai $\mathrm{f} 5$ of $\mathrm{f} 6$ sehari sekarang paling beroentoeng kalaoe memperoleh 2.50 ataoe $\mathrm{f} 3$ sadja (Pewarta Deli, 16 Januari 1931)."

Sejak akhir dekade kedua para sais sebenarnya telah membentuk serikat untuk melindungi usaha mereka atas kemunculan kendaraan mekanis tersebut. Mereka membentuk "Sjarikat Kereta" Pada 1918. Serikat yang berisi orangorang Mandailing, Jawa, Melayu, Keling dan Benggali (A. Harahap, 2014: 92) ini ditujukan untuk melindungi para sais dari ancaman-ancaman atau kebijakan-kebijakan yang berdampak kepada mereka.

\section{Kebijakan Pemerintah Memandang Transportasi}

Peraturan transportasi perkotaan di Medan dilakukan secara otonomi. Sejak menjadi gemeente, peraturan tersebut dilaksanakan secara mutlak. Campur tangan pemerintah kolonial di Batavia kecil sekali peranannya di Sumatera Timur yang berkembang dinamis. Perusahaan swasta di sana mulai melakukan kegiatan dengan derajat otonomi yang cukup luas, dan berkat letaknya, yaitu di pinggiran Hindia-Belanda, dibandingkan dengan daerah lain daerah itu tidak terlalu dikendalikan oleh amtenar pemerintah (Breman, Op. Cit.). Karena itu dalam beberapa kesempatan, aturan dalam transportasi memiliki sedikit intervensi pihak lainnya. Pemerintah, dalam hal ini pemerintah otonomi (Gemeente Medan) memang memiliki peran yang menentukan. Namun, tak bisa ditutupi ada pihak luar yang turut mencampuri kebijakan perkotaan Medan. 
Gemeente Medan dalam pemerintahan kolonial memiliki beberapa aturan berkendara. Terutama untuk kendaraan mekanis. Pada 1917 muncul peraturan penggunaan kendaraan mekanis pertama. Peraturan ini membahas tentang penggunaan kendaraan mekanis yang mulai banyak hadir dan mempengaruhi jalan-jalan perkotaan sejak kehadiran mobil pertama pada 1902.

Peraturan awal tersebut memiliki bagian pasal yang kentara dicampuri oleh pihak luar. Dalam pasal 2 ayat a, b, c, yang menerangkan larangan tentang motor (Pewarta Deli, 6 Juni 1917), pada akhirnya diintervensi oleh kelompok pemilik kendaraan mekanis Deli Automobiel Club (DAC). Menurut DAC bahwa di dalam ayat a, larangan penggunaan lampu yang bikin silau sedikit berlebihan. Hal ini disebabkan bahwa lampu di jalan perkotaan masih kurang untuk menerangi jalan sehingga lampu kendaraan yang terang memang diperlukan untuk keselamatan pengendara sekaligus pengguna jalan yang lain. Untuk ayat b, DAC tidak mempermasalahkan bentuk aturan tersebut karena memang diperlukan. Tetapi ayat c, menurut DAC tak perlu dibuat karena aturan tersebut tidak cocok diterapkan pada kendaraan bermotor. Artinya bahwa aturan tersebut hanyalah kemubajiran.

Salah satu selain hubungan aneh antara aturan transportasi yang dikeluarkan pemerintah gemeente dengan DAC, adalah lirikan pemerintah gemeente dengan perusahaan swasta. Dalam pembangunan memang tak mungkin menutup kerja sama dengan pihak swasta. Tapi apa yang terjadi bila pihak swasta tersebut adalah perusahaan jasa transportasi, yang pengaruhnya bukan hanya di dalam perkotaan, melainkan di seluruh Sumatera Timur. Itulah yang terdapat di sana dengan perusahaannya yang terkenal Deli Spoor Maatschappij (DSM).

DSM punya keuntungan menjadi kuat. Posisinya sebagai anak perusahaan terkuat dan mungkin terbesar dari Deli Maatschappij, memiliki pengaruh yang juga besar berdasarkan induknya tersebut. Aturan perjalanan di seluruh Sumatera Timur digerakkan oleh DSM, dari pengangkutan barang, komoditi, hingga tembakau. Tentu saja pengaruhnya untuk transportasi perkotaan di dalam gemeente lumayan ada. Dalam peta penguasaan tanah di dalam gemeente, salah satunya adalah kepemilikan tanah oleh DSM. Karena itu, perannya sebagai perusahaan ransportasi memiliki pengaruh yang besar pula dalam kebijakan tata kota yang berkaitan dengan moda perjalanan.

Salah satu contoh yang mendukung hubungan antara pemerintah gemeente dengan DSM adalah perbaikan jalan antara Stasiunweg dan Serdangweg. Perbaikan tersebut tidak bisa dilakukan oleh pihak pemerintah sebelum mendapat kesepakatan dengan perusahaan swasta DSM.

"Dahoeloe telah pernah dikabarkan, bahwa gemeente Medan, setelah bertahoen-tahoen lamanja selesai menjoesoen soeatoe rentjana oentoek memperbaiki keadaan perhoeboengan laloe lintas di Serdangweg dikota ini, baroelah sekarang dapat memoelai pekerdjaan itoe, setelah 
D.S.M, dan goebernemen mendapat ketjotjokan satoe sama lain ("Stationweg dan Serdangweg", Pelita Andalas, 5 April 1941.)"

Dalam berita tersebut, biaya perbaikan berjumlah $\mathrm{f}$ 16.500. Biaya tersebut dirasakan besar dan membebani anggaran pemerintah gemeente, sehingga untuk menanggulanginya perlu mengadakan kerjasama perusahaan lain. Sementara itu beban jalan semakin hari semakin meningkat, dan biaya perawatan jalan semakin banyak. Hal ini menyulitkan untuk melakukan perawatan jalan, apalagi bila harus membuat jalan baru. Karena itu, seperti yang dijelaskan sebelumnya pada bab terdahulu, pembangunan jalan perkotaan pada dasarnya tak semaksimal yang dipikirkan dalam sebuah kota modern. Jalan-jalan yang dibangun didasarkan untuk kepentingan golongan tertentu yang berkuasa di perkotaan. Begitu juga dengan peraturan dan kendaraan mekanis yang muncul sesudahnya.

Peraturan kendaraan mekanis, meskipun muncul pada dekade kedua awal abad ke-20, baru menunjukkan aturan yang signifikan pada era 1930-an atau dekade keempat. Masa itu diketahui bahwa industri otomotif memang sedang giat-giatnya berkembang di seluruh dunia. Jerman yang bangkit dari inflasi, dan Jepang yang muncul menjadi kekuatan baru di Asia timur. Kedatangan kendaraan mekanis ke Sumatera Timur pun mengalami kenaikan. Pada 1932 tercatat jumlah sepeda motor yang masuk sampai 591 kendaraan, vracht' auto 590, personen auto 4881 dan autobus 1615 kendaraan ("Banjaknja kendaraan motor di Sumatera Timoer", Pelita Andalas, 11 Januari 1933). Angka ini akan terus bertambah dengan rata-rata 200 buah kendaraan pertahun.

Sementara itu, untuk kebijakan transportasi non-mekanis lainnya, pemerintah juga membuat beberapa aturan. Aturan-aturan tersebut sedikit ketat dan sedikit rumit. Contohnya adalah peraturan dd. 18 November 1922, No. 276 dalam Javasche Courant dd. 31 Desember 1920, No. 105. Aturan tersebut dikenakan ke kereta hongkong, yang berbunyi di art 23:

“Penarik jang dimaksoed dalam art. 20 tida boleh jang berpenjakit pada koelit, koeping ataoe matanja ataoepoen mengandoeng penjakit jang berjangkit, dan pada masa ia bekerdja [menarik hongkong] ia mesti berpakaian bersih ("Oentoek penarik hongkong", Pewarta Deli, 9 Oktober 1922)."

Sebelum kereta hongkong dilarang, pemerintah nampaknya benar-benar memperhatikan kesehatan dan kebersihan kendaraan ini. Meskipun kereta hongkong adalah kendaraan murah dan umum digunakan oleh masyarakat berbagai kelas, kereta hongkong harus memenuhi standar kebersihan yang telah ditetapkan. Namun, aturan yang keluar selanjutnya tak lagi memperhatikan keadaan kendaraan ini, melainkan menghapusnya dari keberadaan transportasi perkotaan di Gemeente Medan. 
Bagi kendaraan non-mekanis lainnya seperti sado dan kereta lembu, aturan yang berlaku adalah pada kebersihan binatang helaan itu sendiri. Terutama kandang. Undang-undang dengan banyak perubahan yang terdapat pada Javasche Courant 31 Desember 1924, menerangkan bahwa perusahan jasa transportasi yang menggunakan hewan perlu memperhatikan kandangnya. Pertama adalah kandang harus punya tempat penyimpanan barang-barang; lebar $25 \mathrm{~cm}$ dan panjang $50 \mathrm{~cm}$; memiliki tempat makan dan satu ember yang dapat dipindahkan; memiliki saluran pemubuangan kotoran hewan; jika terdapat gang di tengah kandang, harus memiliki lebar kurang lebih 1 1/2 meter; si penyewa atau pemakai kandang wajib menjaga kebersihan kandang; memiliki hewan helaan yang baik dan sehat dengan dua kuku dan dua gigi yang lebar (Ontwerp, de Gemeenteraad van Medan, Jaar 1931, Gemeenteblaad II, 1931).

Selain itu, terdapat beberapa aturan yang bisa muncul sewaktu-waktu dan hilang sewaktu-waktu, tergantung kondisi. Seperti aturan penggunaan palang pintu kereta api atau larangan melalui jalan tertentu. Peraturan tersebut muncul akibat terdapat semacam acara atau hajatan yang membutuhkan jalanan lengang.

“....ini kali, segala kendaraan motor dan sado baikpoen kereta hongkong tida diizinkan masoek Cantonstraat ("Tjara mengatoer perhoeboengan kendaraan", Pewarta Deli, 23 April 1934)."

\section{PENUTUP}

Transportasi adalah bagian penting dalam membentuk Medan menjadi kota kolonial pada abad ke-20. Sistem transportasi perkotaan di Medan pada awalnya berasal dari sistem transportasi perkebunan. Jaringan transportasi digunakan untuk memenuhi kebutuhan ekonomi perkebunan sebagai sarana pengangkutan hasil perkebunan. Pada perkembangannya sebagai sistem transportasi perkotaan, penggunaannya berubah dari ekslusif menjadi inklusif.

Berdasarkan hal tersebut di atas, maka ditemukan bentuk yang menjadi ciri transportasi perkotaan di Medan pada paruh pertama abad ke-20. Pertama, kekuasaan pihak swasta (perkebunan) yang cukup kentara terhadap jalan-jalan perkotaan. Meskipun jalan perkotaan telah menjadi jalan inklusif (sarana publik) bagi masyarakat perkotaan, pihak swasta masih menganggap jalan tersebut sebagai bagian ekslusif mereka. Kereta lembu (pedati) yang mengangkut tembakau contohnya, bebas melewati jalan-jalan utama perkotaan, bahkan meskipun jalan yang dilalui diidentifikasi sebagai laan (jalan indah yang di tepinya tumbuh barisan pohon).

Kedua, penggunaan transportasi berdasarkan ciri sosial maupun ekonomi yang berpengaruh besar terhadap morfologi kota. Kendaraan mekanis adalah kendaraan mewah, kepunyaan warga kelas sosial dan ekonomi yang 
tinggi. Jumlah mereka paling sedikit dengan menguasai sebagian besar perekonomian, namun menempati pusat-pusat kota. Sementara pinggiran kota ditempati golongan kelas menengah ke bawah dengan jumlah penduduk paling dominan bagi perkotaan. Kelompok terakhir memiliki aktivitas rutin ke luar, sebab aktivitas utama mereka tak berada di pusat kota, melainkan di pinggiran. Kota Medan tidak berkembang dari industri manufaktur, melainkan industri perkebunan. Hal tersebut juga memperkuat anggapan Jan Breman bahwa Medan memang dipersiapkan untuk hunian para pengusaha, sebagai "kota rekreasi". Di tempat-tempat tertentu dalam kawasan elit perkotaan, kendaraan yang melintas juga punya aturan tertentu sehingga tak semua yang diidentifikasi sebagai transportasi perkotaan bebas melintas di setiap jalan perkotaan.

Ketiga, peran pemerintah yang kurang terlihat dalam mengelola kebijakan transportasi perkotaan. Pengelolaan sistem transportasi perkotaan yang dikelola pemerintah gemeente sering mengalami intervensi berbagai pihak. Kebijakan sering dipengaruhi oleh kelompok-kelompok tertentu, sehingga kebijakan transportasi yang dikeluarkan pemerintah cenderung menyesuaikan diri ke dalam kepentingan beberapa kelompok atau pribadi. Komunitas kendaraan mekanis (baca: kendaraan mewah) seperti Deli Automobiel Club atau transportasi yang dimotori berdasarkan ekonomi seperti perusahaan mobil Rijtuig $\mathcal{E}$ Automobielen adalah pihak-pihak selain pemerintah yang selalu ikut dalam mengelola sebuah kebijakan sistem transportasi perkotaan. Sementara itu, bagi kelompok pribumi, mereka membentuk perkumpulan atau serikat angkutan sewa seperti Sjarikat Kreta dan Chuffeur Bond yang bergerak demi melindungi tarif sewa-karena kepemilikan angkutan publik (terutama angkutan non-mekanis) dikuasai oleh orang-orang Timur Asing-dari keterancaman angkutan publik yang mulai memasuki sistem transportasi perkotaan dengan tarif lebih murah atau kebijakan pemerintah yang mengancam pendapatan mereka.

Keempat, transportasi publik yang tidak didukung oleh sistem yang modern. Meskipun penduduk perkotaan umumnya memiliki mobilitas ke luar, mereka juga memerlukan aktivitas ke pusat kota, meskipun tidak rutin yang sifatnya insidental. Namun, moda (cara) perjalanan yang dibutuhkan tidak memerlukan angkutan yang sifatnya kompleks dan masal. Karena itu, lokomotif lebih digunakan sebagai angkutan ke luar kota daripada sebagai trem di perkotaan. Sementara itu, dibandingkan angkutan masal, kendaraan minim penumpang-baik kendaraan publik atau pribadi-seolah memiliki dukungan pemerintah gemeente karena jumlah kendaraan cukup mempengaruhi pendapatan pemerintah dari sektor pajak. Hal yang mana punya kaitan secara ekonomi, karena di saat yang sama beberapa masyarakat mendapat kesempatan ekonomi dalam usaha menambangkan kendaraan minim penumpang. 
Keempat ciri tersebut adalah dasar penting membedakan kompleksitas sistem transportasi Kota Medan dengan kota-kota besar di Jawa pada paruh pertama abad ke-20. Konsep awal pembentukan kota adalah konsep utama perkembangan sistem transportasi berikutnya. Namun, seperti Chaterine L. Ross katakan bahwa perkembangan kota itu sendiri yang di dalamnya terbentuk atas pola pemukiman, kegiatan sehari-hari, pengaruh sosial, keadaan geografi, ekonomi, dan konsumsi dipengaruhi oleh transportasi (Ross, Loc. Cit). Artinya bahwa transportasi memegang kendali perjalanan sejarah kota. Hal tersebut tak hanya berlaku pada Kota Medan, melainkan pada semua kota-kota di Indonesia. Namun, meskipun kota-kota itu semua bergerak dari awal sejarah kota yang berbeda dengan sistem transportasi yang berbeda pula, entah kenapa selalu sampai kepada sistem transportasi yang sama dalam realitas kekinian dengan wajah kota yang sulit dikenali lagi ciri khasnya, berikut asal-usulnya.

\section{BIBLIOGRAFI}

Apriani Harahap, "Voor Indiers: Sejarah Kehidupan Sehari-hari Orang India di Kota Medan Abad ke-20," TESIS, Yogyakarta: Program Pascasarjana Fakultas Ilmu Budaya UGM, 2014.

Breman, Jan, Menjinakkan Sang Kuli: Politik Kolonial pada Awal Abad Ke-20, Jakarta: PT Pustaka Utama Grafiti, 1997.

Catanese, Anthony J. \& James C. Snyder (ed.), Perencanaan Kota, Jakarta: Penerbit Erlangga, 1996.

Diamond, Jared, Guns, Germs, E Steel (Bedil, Kuman, E Baja): Rangkuman Riwayat Masyarakat Manusia, Jakarta: KPG, 2013.

Gemeenteblaad II, 1931: Ontwerp, de Gemeenteraad van Medan, Jaar 1931.

James Luhulima, Sejarah Mobil E Kisah Kehadiran Mobil di Negeri Ini, Jakarta: Kompas Media Nusantara, 2012.

Khisty, C. Jotin \& B. Kent Lall, Dasar-dasar Rekayasa Transportasi Edisi III, Jakarta: Penerbit Erlangga, 2005.

Pelita Andalas: 11 Januari 1933; 5 April 1941.

Perret, Daniel, Kolonialisme dan Etinisitas: Batak dan Melayu di Sumatera Timur Laut, Jakarta: Kepustakaan Populer Gramedia, 2010.

Pewarta Deli: 6 Juni 1917; 5 Juni 1922; 9 Oktober 1922; 5 Oktober 1927; 15 Februari 1929; 16 Januari 1931; 23 April 1934.

Tengku Luckman Sinar, Sejarah Medan Tempoe Doeloe, Medan: Sinar Budaya Group, 2011.

Verslag betreffende de gemeente Medan het jaar 1919 - 1929. 